\title{
Study on the Persistence of Non-governmental University Mission from the Perspective of Employment
}

\author{
Qiong $\mathrm{Wu}$ \\ School of Education \\ Xi'an Fanyi University \\ Xi'an, China
}

\author{
Jianchang Zhang \\ School of Education \\ Xi'an Fanyi University \\ Xi'an, China
}

\begin{abstract}
In order to meet the needs of transformation of economic society and resolve the structural contradiction in the talent employment demand, local universities, especially nongovernmental universities, should be transformed into application-oriented, and technology-based universities. This has, obviously, become a hot issue. In this craze, it is of great significance to strengthen the rational thinking about the transformation of non-governmental universities. On the basis of the employment survey of university students and the related quality survey of MyCOS Research Institute's, this paper reflects on educational ideas on transformation, positioning of developing goals, approaches to transformation so as to make the transformation of non-governmental universities not deviate from the true essence of education, further improve our talents training work.
\end{abstract}

Keywords-non-governmental university; transformation development; essence of education

employment;

\section{INTRODUCTION}

At present, to solve the social structural contradiction between college students' employment difficulty and shortage of technical talents, education sectors impel systematic management of colleges, guide the transformation of local colleges and seek breakthrough via vocational education reform and deepen employment-oriented teaching reform. Under this background, local colleges explore transformation and development of ordinary colleges. As an important part of higher education, non-governmental universities realize they will fall behind if they don't carry out transformation and development under structural reform and adjustment of higher education system.

\section{DEEPLY UNDERSTAND THE INTERNAL REQUIREMENTS AND RULES OF TRANSFORMATION AND DEVELOPMENT OF \\ NON-GOVERNMENTAL UNIVERSITY}

Transformation is a complex process with contradictions and has motive force and barriers in development. For nongovernmental universities, transformation is normality,

Fund project: Xi'an social science planning fund project (15XF05), this paper is the phased objective of "Analysis on Difficulties in Transformation and Development of Non-governmental University in Xi'an and Countermeasure Research". referring to different school-running forms and connotation at different development phases. Non-governmental higher education has experienced different types at all levels such as self-study aid examination, adult education, academic education, higher vocational education and undergraduate education. With social development and national education reform, school-running types change and school-running level improves, but both "changes" and "improvements" belong to transformation substantially. Non-governmental universities need to plan their development strategies and school-running orientation again in each transformation.

The investigation indicates non-governmental universities insist one development concept, namely: according to social and economic development status and talent shortage, they have to cultivate applied and technical talents with employment orientation, and emphasize operational ability and the ability to adapt to professional posts. Only "smooth employment" can bring "prosperous enrollment". Employment and source of students are distinctly important for non-governmental universities. Transformation is the drive for survival and development of non-governmental universities. Therefore, nongovernmental universities emphasize the conformity between majors and industry, professional post, between course contents and professional standard, between teaching process and production process, continuously deepen talent training pattern in vocational education, in order to meet demands in local economic development and market. At present, it gets support from higher education, local governments and social industrial circle. They think it is inevitable strategic choice for development and approach for transformation of nongovernmental universities. However, we need calm down and think rationally under this circumstance. What are internal requirements and rules for transformation and development under the new situation? What's the relationship between transformation and development and the nature of education? How to formulate strategies under the transformation?

\section{FOLLOW-UP SURVEY ON EMPLOYMENT OF GRADUATES AND CULTIVATION QUALITY}

The advancement of local college transformation is to solve employment difficulty of college students. Non-governmental universities finish their interest demand. Solving graduates' 
employment problem means improving adaptability to the market, get support in enrollment and financial support and become competitive among universities of the same type. However, college students' employment difficulty is very complicated and influenced by university education, economic and social development and family, students' employment attitude and psychological expectation.

\section{A. Destination of Undergraduates after Graduation Shows Multivariate Distribution}

"Fig. 1" indicates the proportion of graduates who "get fulltime job" in 2015 is slightly lower than that of 2014 and 2015.
We can refer to blue book of 2016 Chinese Undergraduate Employment issued by MyCOS Research Institute and data related to students not graduating from "211 Project" universities to deeply think about the relations among employment and talent cultivation, transformation and development through tracking survey data and chart.

It shows downtrend for continuous three years. The proportion of other destinations shows rising trend. (The following data source comes from: MyCOS—-tracking assessment of Chinese 2013-2015 college graduates' cultivation quality.)

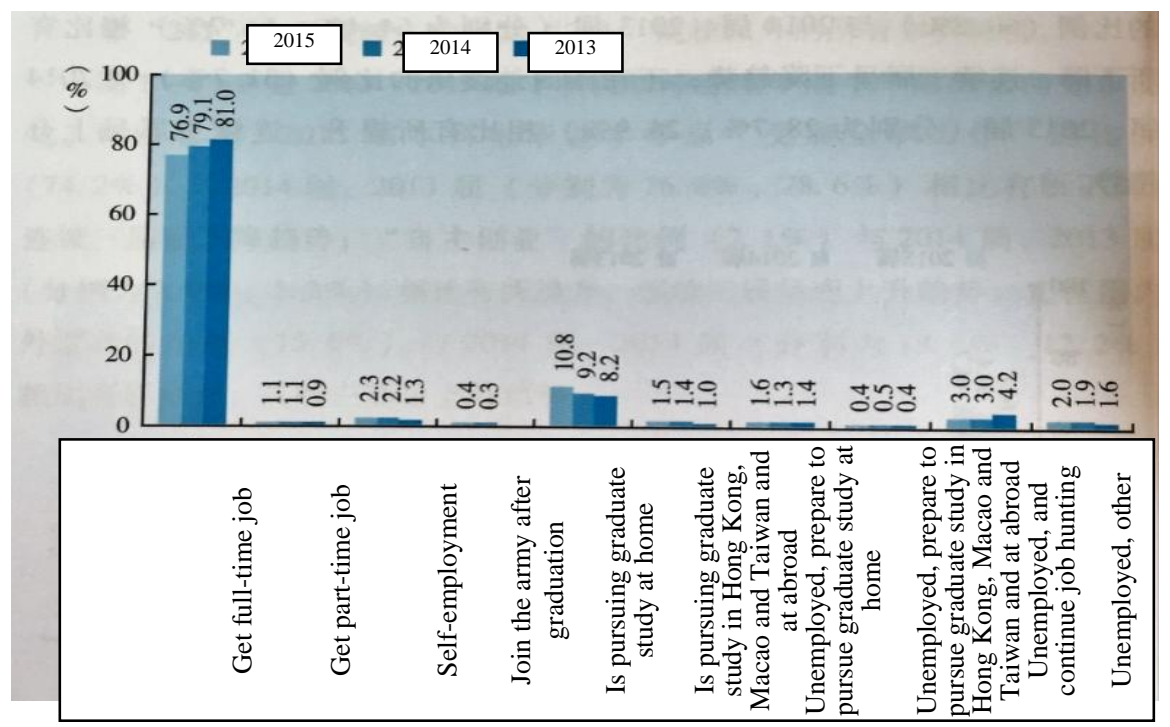

Fig. 1. Distribution change in destination of college students within half a year after graduation from 2013 to 2015 .

\section{B. College Graduates' Work Fails to Conform to Career Expectation and Their Real Work Has Great Difference from Their Majors}

"Fig. 2" indicates 50 percent of college graduates in 2015 realize the conformity between work and career expectation, basically equal to 49 percent in 2014 . "Fig. 3 " indicates 66 percent of college students achieve the conformity between work and major three years after graduation in 2012, down 3 percent than 69 percent of students within half a year after graduation in 2012.

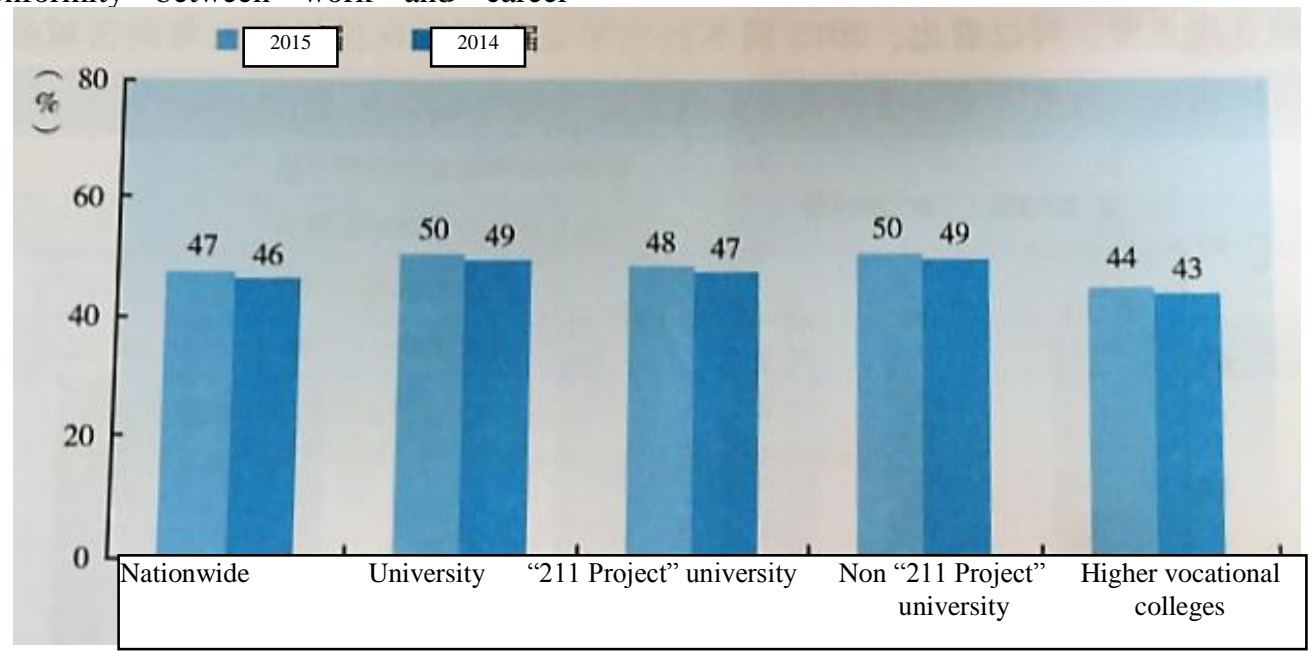

Fig. 2. Goodness of fit between work and career expectation of college graduates in 2014 and 2015 


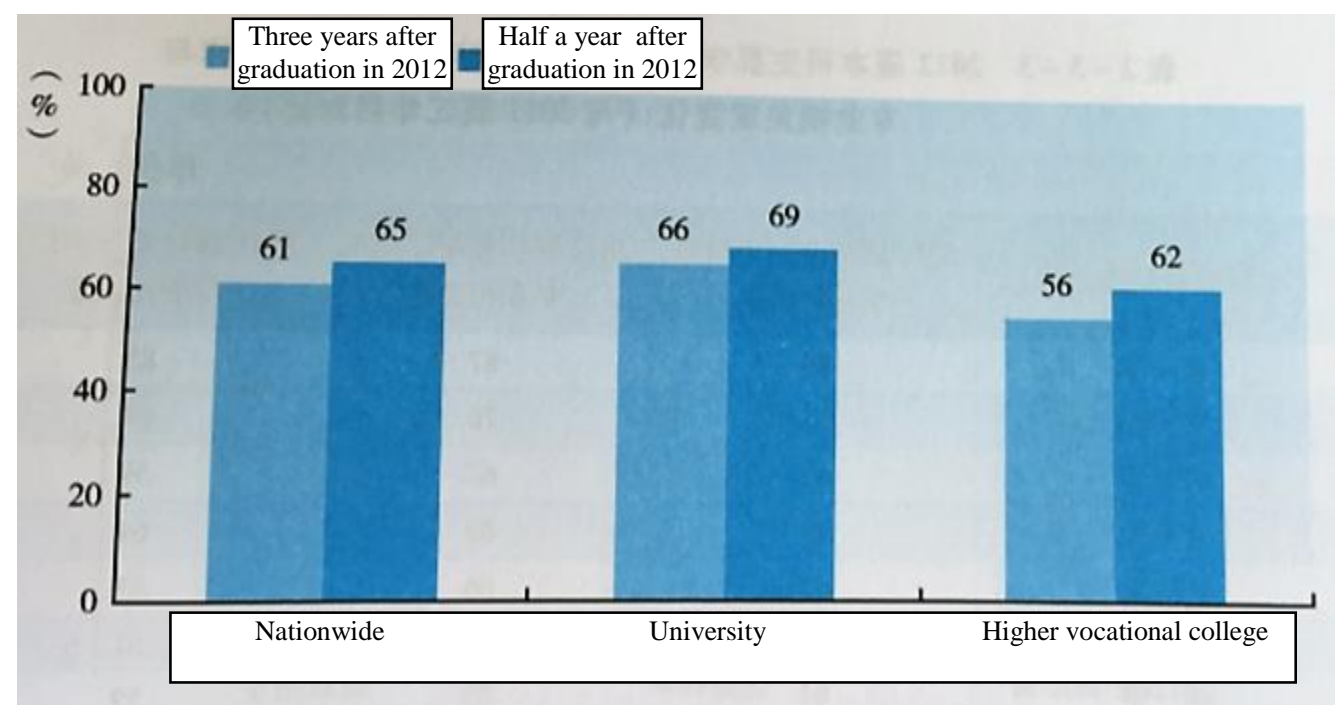

Fig. 3. Relevance proportion between work and major of college students for three years after graduation in 2012.

\section{Basic Service Ability of College Graduates Fails to Meet Position Demands}

The survey data indicate employers' satisfaction degree about professional knowledge of college graduates is 81 percent. ${ }^{1}$ However, compared with professional knowledge, vocational ability is more important in work in modern society. The comparison of data between "Fig. 4" and "Fig. 5 " indicates basic service ability of both university graduates and graduates in higher vocational colleges fails to meet position demands.

\section{Importance of Vocational Ability and Professional Quality in the Opinion of Undergraduates for Three Years after Graduation}

With constant acceleration of knowledge aging and advancement of informatization and intellectualization, core competence of graduates is the key factor for their career development and lifelong development. "Fig. 6" indicates three years after graduation, college students think continuous learning ability is most important ( 85 percent) in workplace, and then self-positioning ability (62 percent), career planning ability $(60 \%)$ and resource control ability (54\%). "Fig. 7" indicates three years after graduation, college students think pressure endurance ability and adaptive capacity to environment are most important in workplace (76\% respectively), and then problem-solving ability (72\%), information acquisition and selection ability (64\%) and sense of responsibility restraint (57\%).

Brief summary: The above data and charts show in social and economic transformation and development of universities, job destination of graduates is diversified. The proportion of graduates who get full-time job declines in continuous three years. Only 50 percent of graduates who have been employed realize the conformity between work and career expectation. Increasing graduates change job and

1 MyCOS Research Institute. 2016 Chinese Undergraduate Employment Report [M], Social Sciences Academic Press, June 2016 leave office. The relevance degree between work and major of graduates three years after graduation declines continuously. According to follow-up survey of graduates' cultivation quality, employers are basically satisfied about the core knowledge grasped by college graduates but their basic ability level fails to meet job demands. In the era with knowledge explosion, refresh cycle of knowledge constantly accelerates. Therefore, compared with knowledge, core vocational quality of graduates is increasingly important.

According to the analysis on survey data of undergraduates' employment and cultivation quality, and the talent training in colleges and the transformation orientation of non-governmental universities, "devote to cultivate technical and professional talents and finally realize high employment rate of graduates", obviously, the transformation orientation seriously tends to train serviceoriented workers with technology and skills for specific work. They fail to consider students' integrated development and train students' quality and ability to face the future full of changes. If non-governmental universities follow this idea, the effect of transformation and development may be simplified as "employment rate". They will mislead talent training and step on "single-log bridge" and enter "dead end". 


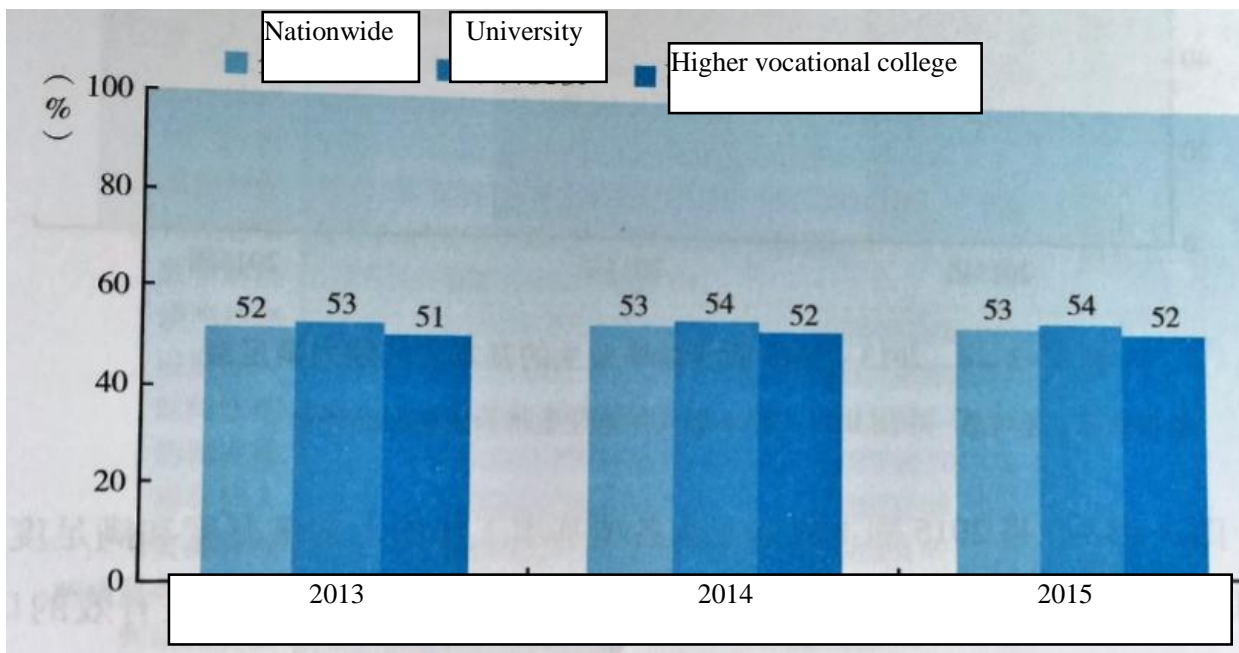

Fig. 4. Basic service ability of college graduates from 2013 to 2015 .

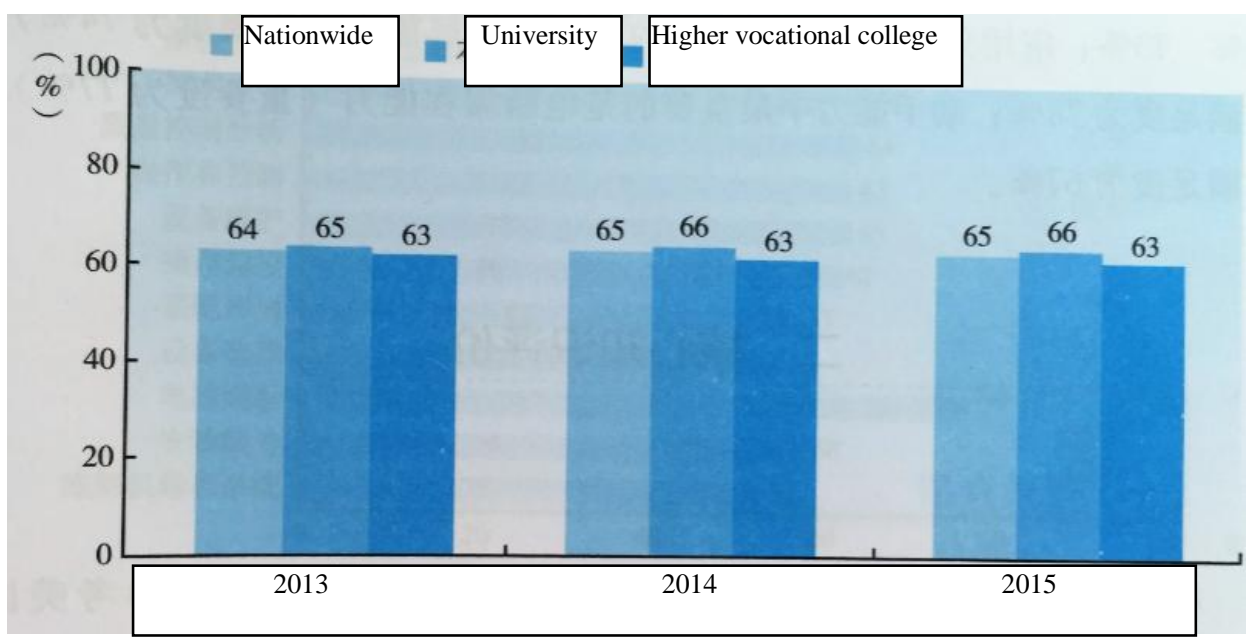

Fig. 5. Basic service ability required by operating posts of graduates from 2013 to 2015 .



Fig. 6. Importance of vocational ability in the opinion of undergraduates for three years after graduation in 2012. 


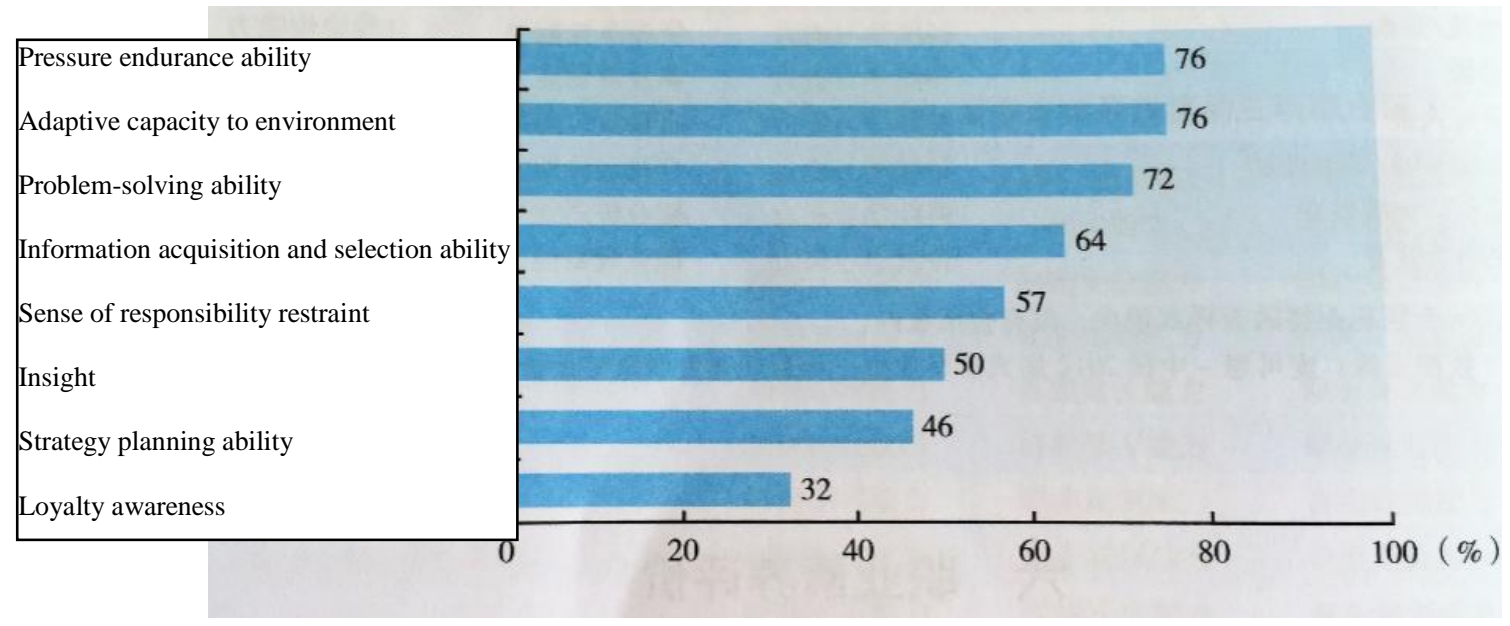

Fig. 7. Importance and professional quality in the opinion of undergraduates for three years after graduation in 2012.

\section{THOUGHTS ON TRANSFORMATION AND}

\section{DEVELOPMENT OF NON-GOVERNMENTAL UNIVERSITY} ACCORDING TO EMPLOYMENT AND QUALITY SURVEY

Development and improvement of non-government funded education face problems like where to go, how to go and how to get there, continuously "transform" in exploration. However, regardless of transformation changes, we cannot forget "we are running school", "we are educating people" and "we have to firmly adhere to educational mission". Since university transformation has become inevitable situation, according to analysis on the above employment data and cultivation quality, the following thoughts are proposed for transformation and development of non-governmental universities.

\section{A. Return to Nature of Education and Guide \\ Transformation and Development with Scientific Educational Idea}

German educator Jaspers said, "Education must change when social changes happen; the reform must first closely question the nature of education". " In order to adapt to transformation and development of economy and society and solve structural contradictions of employment demand, the transformation of local colleges has been imperative. Nongovernmental universities should keep cool and closely question the nature of education, so that they can have rational and scientific educational idea. "Idea guides thought and thought guides actions." Only scientific idea can guide top-level design of transformation and development, guide the implementation of policies in it and guarantee the "transformation" will not deviate from the correct educational direction.

Currently, higher education and talent cultivation in China seriously tend to functional view and utilitarianism. Severe short-term utilitarianism exists at school, individual and social levels. Under the guidance of educational idea

\footnotetext{
2 Jaspers, K.T. What Is Education [M], translated by Zou Jin. Beijing, SDX Joint Publishing Company, 1991:16
}

with "service orientation and employment orientation", and training objective, non-governmental universities pay more attention to transformation and development with "concentration on technical ability", but they should not ignore applied university must be "university" firstly to educate people. Education is the cause and the practical activity facing the future, in order to train students' ability required by social development and changes and let them become innovation pioneer.

\section{B. Establish Career Concept and Refer to Important Enlightenment of American Vocational Education Reform}

American vocational education reform at the turn of the 20th century has important enlightenment significance on transformation and development of local colleges in China. In the 1990s, with scientific and technological development, the employment structure in America changed. To solve the problems that students fail to realize transition from school to work and the unemployment rate increases, the reform of STW (School to Work) is launched in America. However, the reform with short duration stops with the abolition of School-to-Work Opportunity Act and is replaced by STC (School to Career), becoming the new direction for American vocational education reform. Career in STC has richer connotation and makes schools pay more attentions to dynamic and comprehensive education with sustainable development and lifelong benefit. STC idea surpasses narrow educational idea that students adapt to job demands, and provides opportunities for diversified development of students' career and helps students realize the transition from school to career development. ${ }^{4}$ The analysis reports about the destination distribution of graduates shown in Fig. 1 and the importance and professional quality in the opinion of undergraduates for three years after graduation shown in Fig. 6 and Fig. 7 fully explain it.

${ }^{3}$ Dewey, Democratic Education $[\mathrm{M}]$, the $2^{\text {nd }}$ Edition, translated by Wang Chengxu, Beijing People's Education Press, 2001: 16

${ }^{4} \mathrm{Gu}$ Yueqin. From STW to STC: Analysis on American Vocational Education Reform at Turn of the Century [J], Vocational and Technical Education Forum, 2013(3): 90-92 
The core mission of transformation of non-governmental university is to train applied talents. If aiming at solving college students' employment problems, they inevitably deviate from the nature of education, and the transformation will disappear like American STW. Therefore, the transformation and development of non-governmental universities must focus on applied technology education. However, higher education should be all-round qualityoriented education instead of training applied technology and vocational skills. It is "applied or vocational" as well as "educational". Only with wholesome personality, rich personality, sound psychology, positive attitude towards life and noble sentiment can students become talents who can grasp and correctly use applied technology. ${ }^{5}$

\section{Manifest Brand Characteristics and Transform according to Characteristics and Advantages}

After returning to nature of education, surpassing narrow pragmatism related to jobs and establishing the educational idea of training students' diversified career development, to transform substantially, non-governmental universities should further position school-running type and standard for talent training and clarify strategic countermeasures and specific ways for transformation and development according to experience, regional comparative advantage. Furthermore, they must embody characteristics through the unity of knowledge and doing to form brand effect and absolute competitiveness. It is the essence of transformation and development, not blindly pursuing "who I resemble" but achieving "who I am", to form irreplaceable brand.

In constant transformation and development, "who I am" means keeping cool and actively studying and forming brand characteristics. When considering characteristic positioning and development strategies, non-governmental universities must abandon the narrow idea that "university will provide what the market needs". They must gradually improve and accumulate brand characteristics in connotation construction according to existing conditions, objective environment and regional comparative advantage. It is an unbridgeable rule for survival and development of universities. For example, there is a university called Jishou University in Hunan province and it is unimpressive. However, Zhu Rongji, the former Premier of the State Council, said in inspection, "Jishou University is the pride of Hunan!" It is because this school combines characteristics of ethnic minorities in western Hunan and specializes in ethnic language and art of western Hunan. Researches on ethnic minorities at abroad are not separable from Jishou University. This is characteristic of this school which makes it eminent. Therefore, in transformation, universities must base on characteristics and advantages of their own and avoid "sameness and absence of characteristics".

\section{CONCLUSION}

When non-governmental universities and local colleges transform and develop, many domestic key universities are successively publishing opinions on roundly deepening educational reform. Obviously, universities of all types at all levels ceaselessly explore and strive in development. Both transformation and reform are dynamic and need continuous adjustment. We must never forget education is to provide boundless possibilities and opportunities for students to make choice and become better.

\section{REFERENCES}

[1] MyCOS Research Institute. $2016 \quad$ Chinese Undergraduate Employment Report [M], Social Sciences Academic Press, June 2016

[2] Jaspers, K.T. What Is Education [M], translated by Zou Jin. Beijing, SDX Joint Publishing Company, 1991:16

[3] Dewey, Democratic Education [M], the 2nd Edition, translated by Wang Chengxu, Beijing People's Education Press, 2001: 16

[4] Gu Yueqin. From STW to STC: Analysis on American Vocationa Education Reform at Turn of the Century $[\mathrm{J}]$, Vocational and Technical Education Forum, 2013(3): 90-92

[5] Zhang Yingqiang. Two Problems in Chinese Higher Vocational Education Reform [J], Journal of Suzhou University: Education Science Edition, 2014(2): 39-45

[6] Pan Maoyuan. School-running Orientation and Development Characteristics of Newly-built University $[\mathrm{J}]$, Journal of Jingmen Technical College, 2007(2): 1-4

[7] Gu Yongan. Analysis on Problems in Transformation and Development of Newly-built University [J], Modern Education Management, 2010, (11)

[8] Zhang Yingqiang, Jiang Hualin. Thoughts on Problems in Transformation and Development of Local Colleges [J], Modern University Education, 2014)6): 6-8

[9] Richard,K.and Hilary,P.What's Next for School-to-Career Boston,MA:Jobs for Future, 1998:18.

[10] Hu Ruiwen, Zhang Haishui. Talent Supply and Demand in the Popularization Period and Transformation and Development of Higher Education [J], Educational Research, 2014(1): 74-83.

5 Zhang Yingqiang. Two Problems in Chinese Higher Vocational Education Reform [J], Journal of Suzhou University: Education Science Edition, 2014(2): 39-45 